\title{
Influence of Glutamine and Vitamin E on the Performance and the Immune Responses of Broiler Chickens ${ }^{1}$
}

Author(s)
Sakamoto $\mathrm{MI}^{2}$
Murakami $\mathrm{AE}^{3}$
Silveira $\mathrm{TGV} \mathrm{V}^{4}$
Fernandes $\mathrm{JM}^{2}$
Oliveira CAL de

Part of the dissertation thesis of the first
author presented in the Post-Graduation
Program in Animal Science of Universidade
Estadual de Maringá/UEM-PR, financed by
pelo Conselho Nacional de Desenvolvimento
Científico e Tecnológico - CNPq.
2 Post-Graduation Program in Animal Science
of Universidade Estadual de Maringá/UEM-
PR.
3 Department of Animal Science - Post-
Graduation Program in Animal Science of
Universidade Estadual de Maringá/UEM-PR.
Department of Clinical Analyses of
Universidade Estadual de Maringá/UEM-PR.

\section{Mail Address}

Márcia Izumi Sakamoto

Rua Duílio Vasecchi, 204. Apto. 03

Jardim Petrópolis

13.634-304. Pirassununga, SP, Brazil

Email: mizumiss@yahoo.com.br mizumiss@hotmail.com

\section{Keywords}

Antibodies, sheep red blood cells, cutaneous basophilic hypersensitivity.

\section{ABSTRACT}

This study aimed at evaluating the influence of Glutamine (Gln) and Vitamin $E(V E)$ supplementation on the performance and immune response of broilers. A completely randomizes experimental design with a 2 × 3 (VE x GIn) factorial arrangement was used. VE was supplemented at 10 and $500 \mathrm{mg} / \mathrm{kg}$ feed, with or without GIn (1\%) addition, and two periods of supplementation in the starter diets (1-7 and 1-14 days of age), with five replicates of 50 birds each. The analyzed parameters were: live performance (weight gain, feed intake, and feed conversion ratio); relative weights of the spleen, bursa, and thymus; antibody titers (with sheep red blood cells suspension - SRBC) and cutaneous basophilic hypersensivity $(\mathrm{CBH})$. Data were submitted to the analysis of variance, and means were compared using the test of Tukey. Treatments did not influence $(P>0.05)$ live performance parameters or antibody titers. VE reduced $(P=0.01) \mathrm{CBH}$, with the level of $10 \mathrm{mg} V E / \mathrm{kg}$ allowing higher cell proliferation as compared to $500 \mathrm{mg} \mathrm{VE/kg.} \mathrm{As} \mathrm{to} \mathrm{lymphoid} \mathrm{organs,}$ only the spleen was affected $(\mathrm{P}=0.035)$ by $\mathrm{Gln}$, which resulted in higher spleen relative weight when fed during the first week of age. Results showed that $10 \mathrm{mg}$ VE/kg with Gln (1-7 days) promoted better immune responses.

\section{INTRODUCTION}

\section{Action of vitamin $E$ on the immune response}

Vitamin $E(V E)$ is the most widely known natural anti-oxidant, and alpha-tocopherol is its most active biological form for physiological functions, despite its limited efficiency as anti-oxidant. The delta and gamma forms are better anti-oxidants, but are less efficient to support animal growth and performance (Rutz \& Lima, 1994). According to McDowell (1989), DL-alpha-tocopherol power is $1.1 \mathrm{IU} / \mathrm{mg}$ of Vitamin $\mathrm{E}$.

VE donates electrons to free radicals, thereby making them stable. This prevents free radicals from binding to fatty acids, inhibiting oxidations reactions, and therefore maintaining cell membrane integrity (Rutz \& Lima, 1994).

According to Klasing (1998), in addition of being the first line of body defenses against the action of free radicals, protecting the host cells, VE modulates the immune response. It also decreases the synthesis of prostaglandins, leukotrienes, and cytokines, which regulate the inflammatory response, thereby reducing damage caused to the tissues by the inflammatory process.

Chung \& Boren (1999) evaluated the benefits of VE supplementation in broiler diets, and observed that birds fed $240 \mathrm{mg} \mathrm{VE} / \mathrm{kg}$ improved feed conversion ratio in $2.3 \%$ as compared to the control group (33 mg de $V E / \mathrm{kg}$ ). Broilers that received the higher VE level presented reductions of 34,25 , and $61 \%$ in carcass downgrading due to diseases, septicemia/ 
toxemia, and inflammatory processes, respectively, relative to the control group.

On the other hand, Erf et al. (1998) supplemented broiler diets with increasing VE levels $(0,17,46$ e 87 $\mathrm{mg}$ de $\mathrm{dl}$ - $\alpha$-tocopherol/ $/ \mathrm{kg}$ ), did not find effect of VE supplementation on thymus and spleen B lymphocytes and macrophages percentage. However, independent of supplementation level, VE increased T-cell (CD4 ${ }^{+}$and $\left(D 8^{+}\right)$production as compared to birds that did not receive VE supplementation.

Boa-Amponsem et al. (2000) fed broiler diets containing 10 and $300 \mathrm{mg} \mathrm{VE} / \mathrm{kg}$, and challenged the birds with an intravenous solution of sheep red blood cells. There was no effect of VE supplementation on anti-SRBC antibody titers, but the heterophil/ lymphocyte ratio increased, indicating that VE improved the phagocytic capacity of the immune system, protecting the birds against the invasion of pathogenic microorganisms.

Evaluating VE supplementation on $(0,10,25,50$,

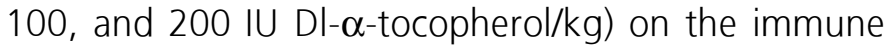
response of broilers, Leshchinsky \& Klasing (2001) observed that VE levels between 25 and $50 \mathrm{IU} / \mathrm{kg}$ (22.73 and $45.45 \mathrm{mg} / \mathrm{kg}$ ) promoted higher antibody titers 7 days after the inoculation of SRBC as compared to higher levels of VE dietary addition.

\section{Glutamine action on the immune response}

Glutamine (Gln) is a free, neutral, non-essential amino acid, which found in higher levels in muscles and plasma, in concentrations representing approximately 50 to $80 \%$ of the total free amino acids content in the body. As it contains in its structure two nitrogen groups that can be mobilized, Gln may be a vehicle for tissue nitrogen exchange, and may play an essential role in several important metabolic pathways (Marliss et al., 1971; Smith, 1990).

Gln is recognizes as a crucial energy substrate for rapidly dividing cells, and may act on the humoral immune response, that is, in certain sites of mucosa membranes, such as the respiratory and gastrointestinal tracts, with increase in the number of lymph nodes in mammals (Newsholme, 2001).

$\mathrm{Yi}$ et al. (2005) observed the importance of Gln supplementation (1\%) in the diet of broilers up to 28 days of age, which presented better performance (weight gain, feed efficiency, and viability) than the nonsupplemented birds. However, these results are not in agreement with the study of Maiorka et al. (2000), who did not find any effect of Gln on the performance of broilers supplemented at the same levels and during the same period.
Although the immunomodulation mechanism of several dietary ingredients is still being researched, the outstanding importance of dietary influence on the immune response should not be underestimated in terms of the general resistance of poultry against infections.

The immune system has one of the most complex molecular and cell interactions in biology, encompassing the cell system (T cells) and the humoral system (B cells), and the lymphocyte is the primary cell in both systems. Antibodies are produced in the secondary lymphoid tissues, which include, in addition to the spleen and the lymph nodes, the bone marrow, the cecal tonsils, and the lymphoid tissue distributed throughout the body, particularly in the respiratory, digestive, and urogenital tracts (Tizard, 1985).

At hatching, the immune system of birds is already partially developed, and the primary organs - thymus and bursa - are present and populated with lymphoid cells. However, the secondary organs, such as spleen, cecal tonsils, Meckel's diverticulum, and lymphoid tissues scattered in the digestive and respiratory tract are still incomplete (Dibner \& Richards, 2004).

Intensive genetic selection for weight gain and feed efficiency caused poultry to be less competent in some aspects of the immune response. When commercial genetic lines of broilers were compared, it was observed that 1991 strains were less efficient in antibody production as compared to 1957 strains. Interestingly, genetic manipulation did not change natural immune response (Qureshi \& Havestein, 1994).

Intensive production systems increase the risk of dissemination of infectious diseases, demanding the adoption of measures to preserve bird health. Production practices, in addition of increasing pathogen lead, also caused changes in the environment, both in terms of climate and behavior, to which broilers were not adapted (Siegel, 1985).

The ban of some feed additives used to improve broiler performances and profitability drove the study of other ingredients that could allow optimal nutrient utilization, favoring the full expression of the genetic potential (Perry, 1995; Rosen, 1996).

Aiming at contributing to broiler nutrition research, and considering the lack of information in literature as to these two nutrients - glutamine and vitamin $\mathrm{E}$ - this experiment evaluated the influence of $G \ln$ and VE supplementation on the performance and on the intensity of the immune response of broilers. 


\section{MATERIAL AND METHODS}

The experiment was carried out at the Poultry Production Sector of Iguatemi Experimental Farm of the State University of Maringá, and at the Animal Nutrition (LANA/DZO) and Immunogenetics (DAC) Laboratories of that university. The experimental procedures were approved by the Committee on Animal Experimentation Ethics - CEEA/UEM.

A total number of 1,500 day-old male CobbVantress ${ }^{\circledR}$ broilers was used. A completely randomized experimental design with a $2 \times 3$ (VE vs. GIn) factorial arrangement was applied. VE levels of 10 and $500 \mathrm{mg}$ (11 and $550 \mathrm{IU} / \mathrm{kg}$, respectively) of Dl- $\alpha$-tocopherol/kg were added to the feed, with or without GIn $(1 \%)$ added during two starter periods (from 1 to 7 days and 1 to 14 days of age), with a total number of six treatments, with five replicates of 50 birds per experimental unit. During the grower state (from 22 to 41 days if age), treatments consisted only of the two different VE levels. The vitamin and mineral premix used in the feeds did not contain VE. Diets contained equal nutrient levels, and were base on corn and soybean meal, being formulated to supply nutritional requirements according to Rostagno et al. (2000). The experimental diets are shown in Tables 1 and 2 .

\begin{tabular}{|c|c|c|c|c|}
\hline \multirow[b]{3}{*}{ Ingredients } & \multicolumn{4}{|c|}{ Vitamin E level (mg/kg feed) } \\
\hline & \multicolumn{2}{|c|}{10} & \multicolumn{2}{|c|}{500} \\
\hline & no Gln & $\begin{array}{c}\text { with Gln } \\
(1 \%)\end{array}$ & no Gln & $\begin{array}{c}\text { with Gln } \\
(1 \%)\end{array}$ \\
\hline Corn grain & 55.86 & 55.86 & 55.77 & 55.77 \\
\hline Soybean meal $45 \%$ & 36.34 & 36.34 & 36.35 & 36.35 \\
\hline Dicalcium phosphate & 1.82 & 1.82 & 1.82 & 1.82 \\
\hline Limestone & 1.08 & 1.08 & 1.08 & 1.08 \\
\hline Soybean oil & 2.85 & 2.85 & 2.88 & 2.88 \\
\hline Salt & 0.40 & 0.40 & 0.40 & 0.40 \\
\hline DL-methionine (99\%) & 0.23 & 0.23 & 0.23 & 0.23 \\
\hline Mineral-vitamin premix ${ }^{2}$ & ${ }^{2} \quad 0.40$ & 0.40 & 0.40 & 0.40 \\
\hline Vitamin $E^{3}$ & 0.001 & 0.001 & 0.05 & 0.05 \\
\hline L-Glutamine 4 & - & 1.00 & - & 1.00 \\
\hline Inert material ${ }^{5}$ & 1.00 & - & 1.00 & - \\
\hline $\mathrm{BHT}^{6}$ & 0.01 & 0.01 & 0.01 & 0.01 \\
\hline Total & 100.00 & 100.00 & 100.00 & 100.00 \\
\hline
\end{tabular}

1 - Calculated requirements: $3.000 \mathrm{kcal} \mathrm{ME} / \mathrm{kg}: 21.50 \% \mathrm{CP}: 1.00 \%$ Ca; $0.45 \%$ Avail. P; $0.90 \%$ met+cys; $1.15 \%$ Lys; $0.20 \% ~ N a ; 0.27 \%$ $\mathrm{Cl} ; 0.84 \%$ K. 2 - Nutritional levels per kg product: vitamin A, 12,500 $\mathrm{Ul}$; vitamin D3, 2,125 $\mathrm{Ul}$; vitamin $\mathrm{K} 3,650 \mathrm{mg}$; thiamin, $2,250 \mathrm{mg}$; riboflavin, 5,100 mg; pyridoxine, 2,475 mg; cyanocobalamine, 14,375 $\mathrm{mcg}$; calcium pantothenate, $14,500 \mathrm{mg}$; niacin, $27,425 \mathrm{mg}$; folic acid, 0,800 mg; choline, 187,500 mg; zinc, $90,740 \mathrm{mg}$; iron, 82,250 $\mathrm{mg}$; copper, 18,120 mg; manganese, 79,137 mg; iodine, 1,239 mg; selenium, 0,363 mg; cobalt, $2,498 \mathrm{mg}$; gentian violet, $3,125 \mathrm{mg}$; BHT, 1,250 mg. 3 - Vitamin E (DI-alfa-tocopherol): $60 \% .4$ - Ajinomoto Interamericana: Analytical results - Transmittance 98\%; Chloride (Cl) $0.020 \%$; Ammonium (NH4) $0.10 \%$; Sulfate (SO4) $0.020 \%$; Iron (Fe) $10 \mathrm{ppm}$; Heavy metals (Pb) 10 ppm; Arsenic (As203) 1 ppm; Loss on drying $0.01 \%$; Assay $100.3 \%$; pH 5.6. 5- Washed sand, replacing used glutamine. 6- Butyl Hydroxi Toluene (Antioxidant).

\begin{tabular}{|c|c|c|}
\hline \multicolumn{3}{|c|}{$\begin{array}{l}\text { Table } 2 \text { - Percentage and calculated }{ }^{1} \text { composition of grower } \\
\text { broiler feeds ( } 21 \text { to } 41 \text { days of age). }\end{array}$} \\
\hline \multirow[b]{2}{*}{ Ingredients } & \multicolumn{2}{|c|}{ Vitamin E level (mg/kg feed) } \\
\hline & 10 & 500 \\
\hline Corn grain & 64.89 & 64.78 \\
\hline Soybean meal $45 \%$ & 29.19 & 29.22 \\
\hline Dicalcium phosphate & 1.58 & 1.58 \\
\hline Limestone & 1.02 & 1.02 \\
\hline Soybean oil & 2.34 & 2.38 \\
\hline Salt & 0.32 & 0.32 \\
\hline DL-methionine (99\%) & 0.19 & 0.19 \\
\hline L-Lysine $\mathrm{HCl}(78 \%)$ & 0.03 & 0.03 \\
\hline Mineral-vitamin premix ${ }^{2}$ & 0.40 & 0.40 \\
\hline Vitamin $\mathrm{E}^{3}$ & 0.001 & 0.05 \\
\hline $\mathrm{BHT}^{4}$ & 0.01 & 0.01 \\
\hline Total & 100.00 & 100.00 \\
\hline
\end{tabular}

1 - Calculated requirements: $3,100 \mathrm{kcal} \mathrm{ME} / \mathrm{kg} ; 19 \% \mathrm{CP} ; 0.90 \%$ Ca; $0.40 \%$ Avail. P; $0.80 \%$ met+cys; $1.00 \%$ Lys; $0.17 \% \mathrm{Na} ; 0.23 \%$ Cl; $0.73 \%$ K. 2 - Nutritional levels per kg product: vitamin A, 12,500 $\mathrm{Ul}$; vitamin D3, 2,125 Ul; vitamin $\mathrm{K} 3,650 \mathrm{mg}$; thiamin, 2,250 mg; riboflavin, 5,100 mg; pyridoxine, 2,475 mg; cyanocobalamine, 14,375 $\mathrm{mcg}$; calcium pantothenate, $14,500 \mathrm{mg}$; niacin, $27,425 \mathrm{mg}$; folic acid, $0,800 \mathrm{mg}$; choline, $187,500 \mathrm{mg}$; zinc, $90,740 \mathrm{mg}$; iron, 82,250 $\mathrm{mg}$; copper, $18,120 \mathrm{mg}$; manganese, $79,137 \mathrm{mg}$; iodine, 1,239 mg; selenium, 0,363 mg; cobalt, 2,498 mg; gentian violet, 3,125 mg; BHT, 1,250 mg. 3 - Vitamin E (Dl-alfa-tocopherol): 60 \%. 4 - Butyl Hydroxi Toluene (Antioxidant).

Feeds were offered according to the established stages. Birds were weighed in the beginning and at the end of each period in order to determined performance (average feed intake, average weight gain, and feed conversion ratio). Mortality, as well as feed residues, was duly recorded to determine true feed intake.

Litter consisted of wood shavings, and was used for $5^{\text {th }}$ time in order to increase challenge during growout. House temperature was daily recorded using a manual thermometer, and the maximum and minimum average temperatures were $30^{\circ} \mathrm{C}$ and $22^{\circ} \mathrm{C}$, respectively. Average relative humidity was $30 \%$. Mortality recorded during the entire experimental period was $1.50 \%$.

\section{Antibody titers (Humoral response)}

On days 14 and 24, two birds were randomly removed from each replicate, and were duly identified with a wing band. These birds were inoculated with $0.5 \mathrm{ml}$ of a suspension of sheep red blood cells (SRBC) diluted in PBS (phosphate buffered saline solution) at $0.5 \%$. Inoculation was intramuscular in five equally distant points in the bird's breast, injecting $0.1 \mathrm{ml}$ per point. On days 14 and 35 (days 0 and 21 after the first inoculation), blood was collected from the brachial vein, $3 \mathrm{ml} / \mathrm{bird}$. Blood was centrifuged at 3,000 rpm for 10 min, and the obtained serum were stored in duly identified $1-\mathrm{ml}$ Eppendorf tubes in a freezer at $-20^{\circ} \mathrm{C}$ until analyses. Before analyses, the serum were 
inactivated in water batch at $56^{\circ} \mathrm{C}$ for 30 min, using as diluent buffer PBS with $1 \%$ bovine serum albumin (BSA/Fort Dodge ${ }^{\circledR}-22 \%$ ). Humoral specific immune response was assessed by determination of anti-SRBC antibody titer, using the technique of simple hemagglutination, as described by Wegmann \& Smithies (1965).

Two other birds per replicate were submitted to the same procedure, but these birds were injected with saline solutions to be used as negative controls. Titers were expressed as $\log _{2}$ of the highest dilution observed in agglutination.

\section{Cutaneous Basophilic Hypersensitivity - CBH (Cell Response)}

At 36 days of age, two birds per replicate were used to assess late unspecific immune response. Each bird was identified with a band in the left wing, and submitted to intradermal inoculation in the inter-digital space between the $3^{\text {rd }}$ and the $4^{\text {th }}$ finger of the right foot with $100 \mu \mathrm{g}$ of phytohemagglutinin-P (PHA-P Gibco $^{\circledR}$ ), diluted in sterile saline solution, at a dose of $0.10 \mathrm{ml}$. An equivalent volume of sterile saline solution was injected in the same inter-digital space on the left foot for negative control.

Skin thickening of the inter-digital space was measured in millimeters in both feet using a manual pachymeter immediately before injection (time zero), 6,12 , and 24 hours after PHA-P injection. The response to cutaneous hypersensitivity test was calculated as follows (Corrier \& DeLoach, 1990):

\section{$\mathrm{CBH}=\mathrm{PHA}-\mathrm{P}$ response (right foot) - control response (left foot)}

Where:

PHA-P response $=$ post-injection thickening (right foot) - thickening at time zero (right foot)

Control response $=$ post-injection thickening $($ left foot) - thickening at time zero (left foot)

\section{Relative weight of lymphoid organs}

At 41 days of age, two birds per replicate were sacrificed by electric stunning, followed by bleeding, in order to collect the spleen, the thymus, and the bursa. Relative weight of each organ was calculated as follows:

$$
\begin{gathered}
\text { Relative weight }=\text { (organ weight/live body } \\
\text { weight) } \times 100
\end{gathered}
$$

\section{Statistical analysis}

Data obtained for each parameter were submitted to analysis of variance, and means were tested $(P \leq 0.05)$, according to their distributions, using the GLM procedure of SAS software (2000). Polynomial regression was applied to $\mathrm{CBH}$ (cell immunity) data as a function of measured hours.

The following statistical model was applied:

$$
Y_{i j k}=m+V_{i}+G_{j}+V G_{i j}+e_{i j k}
$$

Where:

$Y_{i j k}=$ observation of the $i^{\text {th }}$ replicate submitted to treatment of level $V_{i}$, and $G_{j}$;

$\mathrm{m}$ = general mean of all observations;

$V_{i}=$ effect of the i level of VE supplementation, $i=1,2(1=10 ; 2=500 \mathrm{mg} \mathrm{VE} / \mathrm{kg})$;

$\mathrm{G}_{\mathrm{j}} \quad=$ effect of $\mathrm{j}$ period with $\mathrm{G} \ln (1 \%), \mathrm{j}=1,2,3$ ( 1 = exempt; $2=$ from 1 to 7 days; $3=$ from 1 to 14 days of age);

$V G_{i j}=$ effect of VE vs. GIn interaction;

$\mathrm{e}_{i \mathrm{ij}}=$ experimental error.

\section{RESULTS AND DISCUSSION}

Average results of performance characteristics are presented in Table 3. There was no effect $(P>0.05)$ of GIn and VE association on broiler performance during the studied rearing periods; however, low mortality percentage was observed during the entire experimental period. Reused wood shavings litter did not pose higher challenge. Our results are consistent with those of Maiorka et al. (2000), who did not observe any effect of GIn supplementation on broiler performance, and with those of Konjufca et al. (2004), who evaluated different VE levels, but no effects on broiler body weight were found. On the other hand, Yi et al. (2005) reported better feed efficiency, weight gain, and viability of broilers fed $1 \%$ Gln.

In terms of lymphoid organ relative weight, only the spleen was affected $(P=0.035)$ by $G$ In feeding during the starter period. Birds fed Gln during the first week of age presented higher relative spleen weight, as shown in Table 4. The rate of Gln utilization is high in isolated cells of the immune system, such as lymphocytes, macrophages, and neutrophils. In addition, GIn is important for lymphocyte proliferations, cytokine production, as well as for the activities of phagocytosis and secretion by the macrophages (Newsholme, 2001). These reasons could therefore 


\begin{tabular}{|c|c|c|c|c|c|c|c|}
\hline \multirow{2}{*}{ Treatment } & \multicolumn{2}{|c|}{ Vitamin E (mg/kg) } & \multicolumn{3}{|c|}{ Glutamine } & \multirow[t]{2}{*}{ MEAN } & \multirow[b]{3}{*}{ CV $(\%)$} \\
\hline & 10 & 500 & 0 & 1 - 7 days & 1 - 14 days & & \\
\hline Period (days) & & & Final Weight (g) & & & & \\
\hline 1 to 7 & 168.267 & 165.574 & 164.680 & 168.382 & 167.700 & 166.921 & 3.25 \\
\hline 1 to 14 & 442.994 & 437.757 & 437.241 & 441.469 & 442.416 & 440.376 & 3.13 \\
\hline 1 to 21 & 875.564 & 879.388 & 875.863 & 887.565 & 869.000 & 877.476 & 3.51 \\
\hline 1 to 41 & 2612.385 & 2619.838 & 2610.463 & 2613.215 & 2624.657 & 2616.112 & 2.49 \\
\hline \multicolumn{8}{|c|}{ Weight Gain (g) } \\
\hline 1 to 7 & 123.530 & 120.798 & 120.084 & 123.654 & 122.756 & 122.165 & 4.24 \\
\hline 1 to 14 & 398.258 & 392.981 & 392.645 & 396.741 & 397.472 & 395.619 & 3.42 \\
\hline 1 to 21 & 830.828 & 834.612 & 831.267 & 842.837 & 824.056 & 832.720 & 3.68 \\
\hline 1 to 41 & 2567.649 & 2575.062 & 2565.867 & 2568.487 & 2579.713 & 2571.356 & 2.53 \\
\hline \multicolumn{8}{|c|}{ Feed Intake (g/bird) } \\
\hline 1 to 7 & 139.520 & 136.840 & 136.520 & 139.660 & 138.360 & 138.180 & 3.52 \\
\hline 1 to 14 & 507.133 & 500.951 & 500.960 & 505.077 & 506.089 & 504.042 & 2.55 \\
\hline 1 to 21 & 1154.445 & 1147.962 & 1145.577 & 1155.748 & 1152.285 & 1151.203 & 2.39 \\
\hline 1 to 41 & 4464.532 & 4484.482 & 4481.110 & 4463.683 & 4478.727 & 4474.506 & 2.20 \\
\hline \multicolumn{8}{|c|}{ Feed Conbversion Ratio (g/g) } \\
\hline 1 to 7 & 1.129 & 1.133 & 1.137 & 1.129 & 1.127 & 1.131 & 1.71 \\
\hline 1 to 14 & 1.273 & 1.275 & 1.276 & 1.273 & 1.273 & 1.274 & 1.37 \\
\hline 1 to 21 & 1.390 & 1.376 & 1.379 & 1.371 & 1.399 & 1.383 & 1.86 \\
\hline 1 to 41 & 1.739 & 1.741 & 1.747 & 1.738 & 1.736 & 1.740 & 1.46 \\
\hline \multicolumn{8}{|c|}{ Total Cumulative Mortality (\%) } \\
\hline 1 to 7 & & & 0.13 & & & & \\
\hline 1 to 14 & & & 0.34 & & & & \\
\hline 1 to 21 & & & 0.49 & & & & \\
\hline 1 to 41 & & & 1.50 & & & & \\
\hline
\end{tabular}

$(P>0.05) .1-C V(\%)$ of treatment mean.

\begin{tabular}{|c|c|c|c|c|}
\hline & Spleen & Bursa & Thymus & Bursometer ${ }^{1}$ \\
\hline \multicolumn{5}{|c|}{ Vitamin E (mg/kg) } \\
\hline 10 & 0.126 & 0.063 & 0.475 & 4.233 \\
\hline 500 & 0.129 & 0.060 & 0.479 & 4.133 \\
\hline P-value & 0.418 & 0.515 & 0.868 & 0.383 \\
\hline \multicolumn{5}{|l|}{ Glutamine (1\%) } \\
\hline 1- No Glutamine & $0.131 \mathrm{ab}$ & 0.066 & 0.477 & 4.200 \\
\hline 2- 1 to 7 days & $0.134 a$ & 0.061 & 0.460 & 4.150 \\
\hline 3- 1 to 14 days & $0.121 b$ & 0.057 & 0.492 & 4.200 \\
\hline P-value & * 0.035 & 0.182 & 0.475 & 0.918 \\
\hline$V E^{*} \mathrm{G} \ln (P$-value $)$ & 0.383 & 0.625 & 0.692 & 0.467 \\
\hline CV $(\%)$ & 11.92 & 23.82 & 16.08 & 10.54 \\
\hline
\end{tabular}

* Different letters in the same column are significantly different by the test of Tukey $(P \leq 0.05)$. 1 - Mean bursa size values as measured by the ruler Solvay-Bursine ${ }^{\circledR}-2$.

justify the increase in spleen relative weight observed in the present experiment.

Vitamin $E$ did not influence $(P>0.05)$ the relative weight of the studied organs, which is in agreement with Gore \& Qureshi (1997), who did not observe any difference in the relative weight of the spleen and the bursa of 35-day-old broilers that had received $10 \mathrm{IU}$ vitamin $\mathrm{E}$ as embryos on the $18^{\text {th }}$ day of incubation. Konjufca et al. (2004), evaluating VE supplementation as $\mathrm{Dl}$ - $\alpha$-tocopherol, did not find differences in organ relative weight, except for the spleen, which presented an increase in the $7^{\text {th }}$ week of age of broilers fed 110 and $220 \mathrm{mg} V E / \mathrm{kg}$ as compared to control birds fed 16 $\mathrm{mg} V E / \mathrm{kg}(0.14,0.18$, and 0.10 , respectively).

The studied VE levels presented similar behavior as to cell immune response (cutaneous basophilic hypersensitivity $-\mathrm{CBH}$ ). $\mathrm{CBH}$ response was decreasingly detected as measured times decreased. At 12 hours after inoculation, the level of $10 \mathrm{mg} V E / \mathrm{kg}$ promoted higher cell proliferation as compared to the $500 \mathrm{mg}$ VE/kg level. This effect was no longer observed 24 hours after inoculation, as seen in Table 5. VE supplementation higher than the NRC (1994) recommendations had an inhibitory effect on T-helper cells, as also observed by Boa-Amponsem et al. (2000), who found a higher $\mathrm{CBH}$ level in birds treated with 10 IU VE $/ \mathrm{kg}(x=0.40 \pm 0.03 \mathrm{~mm})$ as compared to $300 \mathrm{IU}$ $V E / k g(x=0.30 \pm 0.03 \mathrm{~mm}) 24$ hours after inoculation.

Using a single PHA-P inoculation, $\mathrm{CBH}$ response provides pre-immunization information in a short period of time. This response to a cutaneous test allows the assessment of the immunocompetence of T-helper cells in newly-hatched birds. Corrier \& DeLoach (1990) evaluated the effect of different PHA-P doses (100 and $200 \mu \mathrm{g}$ ) on cutaneous hypersensitivity of broilers in the starter period (up to 14 days of age), and observed the presence of T-helper cells already in 3-day-old birds, which skin thickness was first observed 6 hours postinoculation, reached its maximum level 12 hours, and 


\begin{tabular}{|c|c|c|c|c|}
\hline \multirow[b]{2}{*}{ Vitamin E } & \multicolumn{3}{|c|}{ Measurement time (hours) } & \multirow[b]{2}{*}{ CV (\%) } \\
\hline & 6 & 12 & 24 & \\
\hline $10^{3}$ & $0.577 \pm 0.025$ & $0.524 \pm 0.021 \mathrm{a}$ & $0.299 \pm 0.018$ & 24.18 \\
\hline $500^{4}$ & $0.552 \pm 0.027$ & $0.483 \pm 0.023 b$ & $0.250 \pm 0.014$ & 25.17 \\
\hline
\end{tabular}

1- $\mathrm{CBH}=$ (thickening, PHA-P / right foot) - (thickening, control-saline solution / left foot). 2- Mean \pm standard error. 3- $\mathrm{CBH}=0,6900-0,0159524 * X$ $\left(R^{2}=0,53\right) ;-C B H=0,6683-0,0171429 * X\left(R^{2}=0,59\right) ; *$ Different letters in the same column are significantly different by the test of Tukey $(P \leq 0.05)$

\begin{tabular}{|c|c|c|c|c|c|c|}
\hline & \multicolumn{2}{|c|}{ Vitamin E (mg/kg) } & \multicolumn{3}{|c|}{ Glutamine (1\%) } & \multirow[t]{2}{*}{ CV (\%) } \\
\hline & 10 & 500 & 0 & 1 - 7 days & $1-14$ days & \\
\hline Antibody titer ${ }^{1}$ & 2.733 & 2.400 & 2.500 & 2.650 & 2.550 & 25.05 \\
\hline Standard error & 0.348 & 0.320 & 0.316 & 0.428 & 0.496 & \\
\hline
\end{tabular}

1 - Values expressed as $\log _{2}$ of the highest dilution observed in Agglutination ( $\left.P>0.05\right)$.

decreased 24 hours post-inoculation. Conversely, Leshchinsky \& Klasing (2001) did not find any effect of VE supplementation on CBH of broilers.

In terms of humoral immune response, average antibody titers are presented in Table 6 . There was no effect $(P>0.05)$ of the treatments on antibody titers of birds at 35 days of age. However, birds treated with $10 \mathrm{mg} \mathrm{VE} / \mathrm{kg}$ and Gln during the first week of age produced more antibodies.

Gore \& Qureshi (1997) injected VE as DI- $\alpha$ tocopherol in turkey embryos at 18 days of incubation, and observed that birds receiving $10 \mathrm{IU}$ VE/kg presented higher antibody titers as compared with those that did not receive VE (4.2 vs. 3.0) at 14 days after SRBC inoculation. This suggests that VE may have an immunomodulator effect, increasing the resistance to diseases. A possible mechanism of this enhanced immune function may be a down regulation of the biosynthesis of prostaglandins, which inhibit several immunity parameters.

The results of the present experiment are similar to those observed by Boa-Amponsem et al. (2000), who did not find significant effect of vitamin $E$ (levels of 10 and $300 \mathrm{lU} / \mathrm{kg}$ ) on average antibody titers of broilers inoculated with SRBC, as measured 20 days after inoculation.

Yang et al. (2000) studied chickens with high and low antibody production and VE (10 and $300 \mathrm{lU} / \mathrm{kg}$ ), and verified a decrease in antibody titers in chickens with low genetic potential fed the high VE level at 6 and 10 days after inoculation with SRBC (2.4 vs. 1.5 on day 6; and 1.9 vs. 1.2 on day 10, for 10 and 300 IU VE/ $\mathrm{kg}$, respectively).

On the other hand, Leshchinsky \& Klasing (2001) found an increase in the antibody titers of broilers supplemented with 50 IU VE/kg ( $x=3.35$ at 7 days after inoculation), and concluded that moderate VE levels
(25 to $50 \mathrm{lU} / \mathrm{kg}$ ) promoted better immunomodulation than high VE levels (100 to 200 IU/kg), which correspond to the VE levels needed for the inhibition of lipid peroxidation, and for the protection of liver mitochondria against oxidative stress.

\section{CONCLUSIONS}

The association of $10 \mathrm{mg}$ vitamin E/ $\mathrm{kg}(11 \mathrm{lU} / \mathrm{kg})$ with Glutamine (during the first 7 days of age) in the feed of broilers promoted better immune response, but did not influence broiler performance.

\section{REFERENCES}

Boa-Amponsem K, Price SEH, Picard M, Geraert PA, Siegel PB Vitamin $E$ and immune responses of broiler pureline chickens. Poultry Science 2000; 79:466-470

Chung TK, Boren B. Vitamin E use in commercial flocks examined. Feedstuffs 1999; 6:11-14

Corrier DE, DeLoach JR. Evaluation of cell-mediated cutaneous basophil hypersensibility in young chickenes by an interdigital skin test. Poultry Science 1990; 69:403-408.

Dibner JJ, Richards JD. The digestive system: challenges and opportunities. Journal Applied Poultry Research 2004; 13:86-93.

Erf GF, Bottje WG, Bersi TK, Headrick MD, Fritts CA. Effects of dietary vitamin $E$ on the immune system in broilers: altered proportions of CD4 T cells in the thymus and spleen. Poultry Science $1998 ; 77: 529-537$

Gore $A B$, Qureshi MA. Enhancement of humoral and cellular immunity by vitamin $\mathrm{E}$ after embryonic exposure. Poultry Science 1997; 76:984-991.

Klasing KC. Nutritional modulation of resistance to infectious diseases. Poultry Science 1998; 77:1119-1125.

Konjufca VK, Bottje WG, Bersi TK, Erf GF. Influence of dietary vitamin 
E on phagocytic functions of macrophages in broilers. Poultry Science 2004; 83:1530-1534.

Leshchinsky TV, Klasing KC. Relationship between the level of dietary vitamin $\mathrm{E}$ and the immune response of broiler chickens. Poultry Science 2001; 80:1590-1599.

Maiorka A, Silva AVF, Santin E, Borges SA, Boleli IC, Macari M. Influência da suplementação de glutamina sobre o desempenho e o desenvolvimento de vilos e criptas do intestino delgado de frangos. Arquivo Brasileiro de Medicina Veterinária e Zootecnia 2000; 52(5):487-490.

Marliss EB, Aoki TT, Pozefsky T, Most AS, Cahill Jr GF. Muscle and splanchnic glutamine and glutamate metabolism in post absortive and starved man. Journal of Clinical Investigation 1971; 50:814817.

McDowell LR. Vitamins in animal nutrition: comparative aspects to human nutrition. London: Academic Press; 1989. p. 93-131.

National Research Council - NRC. Nutrient requirements of domestic animals. $9^{\text {th }}$ ed. Washington, DC; 1994.

Newsholme P. Why is L-Glutamine metabolism important to cells of the immune system in health, postinjury, surgery or infection? Journal of Nutrition 2001; 131:2515S-2522S

Perry FG. Biotechnology in animal feeds and animal feeding: an overview. In: Wallace RJ, Cheson A. Biotechnology in animal feeds and animal feeding. Local: Editora; 1995. p.1-15.

Qureshi MA, Havestein GB. A comparison of the immune performance of a 1991 commercial broiler with a 1957 randombred strain when fed "typical" 1957 and 1991 broiler diets. Poultry Science 1994; 73:1805-1812.

Rosen GD. Feed additive nomenclature. World's Poultry Science Journal 1996; 52:53-57.

Rostagno HS, Albino LFT, Donzele JL, Gomes PC, Ferreira AS, Oliveira RF, Lopes DC. Tabelas brasileiras para aves e suínos: composição de alimentos e exigências nutricionais. Viçosa: Editora Imprensa Universitária; 2000.

Rutz R, Lima GJMM. Uso de antioxidantes em rações e subprodutos. In: Conferência Apinco de Ciência e Tecnologia Avícolas; 1994; Santos, São Paulo. Brasil. Anais... Santos: Facta; 1994. p.73-84.

SAS INSTITUTE. SAS user's guide, statistics, versão 8.1. $4^{\text {th }} \mathrm{ed}$. Cary, 2000.

Siegel HS. Immunological responses as indicators of stress. World's Poultry Science Journal 1985; 41:36-44.

Smith RJ. Glutamine metabolism and its physiologic importanee. Journal of Parenter Enteral Nutrition 1990; 14:40S-44S.

Tizard I. Introdução à imunologia Veterinária. 2.ed. São Paulo: Editora Roca; 1985.

Wegmann TG, Smithies O. A simple hemagglutination system requiring small amounts of red blood cells and antibodies. Transfusion 1965; 6:67-73.

Yang N, Larsen CT, Dunnington EA, Geraert PA, Picard M, Siegel PB. Immune competence of chicks from two lines divergently selected for antibody response to Sheep Red Blood Cells as affected by supplemental vitamin E. Poultry Science 2000; 79:799-803.

Yi GF, Allee GL, Knight CD, Dibner JJ. Impact of glutamine and oasis hatchling supplement on growth performance, small intestinal morphology, and immune response of broilers vaccinated and challenged with Eimeria maxima. Poultry Science 2005; 84:283293. 